\title{
The ancient koji mold (Aspergillus oryzae) as a modern biotechnological tool
}

\author{
Ghoson M. Daba* ${ }^{*}$, Faten A. Mostafa* and Waill A. Elkhateeb
}

\begin{abstract}
Aspergillus oryzae (A. oryzae) is a filamentous micro-fungus that is used from centuries in fermentation of different foods in many countries all over the world. This valuable fungus is also a rich source of many bioactive secondary metabolites. Moreover, A. oryzae has a prestigious secretory system that allows it to secrete high concentrations of proteins into its culturing medium, which support its use as biotechnological tool in veterinary, food, pharmaceutical, and industrial fields. This review aims to highlight the significance of this valuable fungus in food industry, showing its generosity in production of nutritional and bioactive metabolites that enrich food fermented by it. Also, using $A$. oryzae as a biotechnological tool in the field of enzymes production was described. Furthermore, domestication, functional genomics, and contributions of A. oryzae in functional production of human pharmaceutical proteins were presented. Finally, future prospects in order to get more benefits from A. oryzae were discussed.
\end{abstract}

Keywords: Aspergillus oryzae, Food industry, Enzymes, Secondary metabolites, Functional genomics

\section{Introduction}

Aspergillus oryzae (A. oryzae) is a multicellular fungus that is considered as one of the most important species used as biotechnological tool in many countries all over the world as shown in Table 1. It is generally used in food industry for manufacturing fermented foods such as miso (soybean paste), shoyu (soy sauce), tane-koji (seed rice malt), douche (fermented and salted black soybean), bean curd seasoning and vinegar. Thanks to its potent ability to produce amylase and protease that allows it to decompose proteins and different starches into sugars and amino acids (Watarai et al. 2019). For more than 2 millennia, A. oryzae has been employed for koji production in the Orient. In Europe, A. oryzae has been used since the beginning of the previous century in enzyme production for brewing and baking (Barbesgaard et al. 1992). In the Japanese cuisine, koji is soya beans and/or cooked grain that have been fermented with a certain mold, this mold was then named koji mold to indicate the

\footnotetext{
*Correspondence: gm.daba@nrc.sci.eg; fatenahmedalimostafa@yahoo.com Chemistry of Natural and Microbial Products Department, Pharmaceutical Industries Researches Division, National Research Centre, El Buhouth Street, Dokki, Giza 12311, Egypt
}

mold used for koji fermentation (Gomi 2019). A. oryzae has been regarded as safe (GRAS) by the FDA, and this mold safety has been approved also by the WHO (He et al. 2019). Besides its known industrial applications, $A$. oryzae has many reported biological activities that nominate it as a promising probiotic in the veterinary field for animal production (Lee et al. 2006). A. oryzae contributes positively in affecting gut microflora by acting as a favorable substrate for the growth of many beneficial bacteria inside intestine such as different lactobacilli species which subsequently antagonize harmful bacteria as $E$. coli and Salmonella due to the ability of many lactobacilli to produce bacteriocins (antimicrobial peptides) (Kim et al. 2003). Moreover, the potent enzymes produced by $A$. oryzae affect digestion process and active amylolytic and proteolytic facilitate digestion of dry matter and hence simplify getting nutrients. In a recent study, combining A. oryzae with date palm seed meal resulted in improving Nile tilapia's growth, digestion activity and immunity (Dawood et al. 2020). Similarly, addition of A. oryzae at $0.1 \%$ to a diet resulted in a significant lowering of cholesterol levels in serum of broiler chickens for 5 weeks (Kim et al. 2003) which came as a result of the production of
Springer Open (c) The Author(s) 2021. This article is licensed under a Creative Commons Attribution 4.0 International License, which permits use, sharing, adaptation, distribution and reproduction in any medium or format, as long as you give appropriate credit to the original author(s) and the source, provide a link to the Creative Commons licence, and indicate if changes were made. The images or other third party material in this article are included in the article's Creative Commons licence, unless indicated otherwise in a credit line to the material. If material is not included in the article's Creative Commons licence and your intended use is not permitted by statutory regulation or exceeds the permitted use, you will need to obtain permission directly from the copyright holder. To view a copy of this licence, visit http://creativeco mmons.org/licenses/by/4.0/. 
Table 1 Products of commercial values showing importance of A. oryzae as biotechnological tool

\begin{tabular}{|c|c|c|}
\hline Product & Application & References \\
\hline Dry lyophilized powder of A. oryzae & Probiotic; functional feed additive & Lee et al. 2006; Murphy et al. 2021 \\
\hline A. oryzae mycelia & $\begin{array}{l}\text { Fermented foods industry (miso, shoyu, tane-koji, douche, bean } \\
\text { curd seasoning, vinegar) }\end{array}$ & Taylor and Richardson 1979; Yasui et al. 2020 \\
\hline $\begin{array}{l}\text { Amylases (a-amylases, } \beta \text {-amylases, } \\
\text { and glucoamylases) }\end{array}$ & $\begin{array}{l}\text { Food industry (Produced glucose during the initial stage of } \\
\text { starch hydrolysis) } \\
\text { Alcohol production }\end{array}$ & $\begin{array}{l}\text { Chang et al. } 2014 \\
\text { Rodriguez et al. } 2006 \\
\text { James and Lee 1997; Biesebeke et al. } 2005\end{array}$ \\
\hline Lipase & Laundry detergent & Christensen et al. 1988; Machida et al. 2008 \\
\hline Taka-diastase & Stomach medicine & Takamine 1894 \\
\hline Cellulases & Pollution treatment; animal feed, food industry; textile & Bhat et al. 2000; Chen et al. 2012 \\
\hline Pectinases & $\begin{array}{l}\text { Juice and beverage processing, vegetable oil extraction and other } \\
\text { food industries }\end{array}$ & Pinheiro et al. 2017 \\
\hline$\beta$-galactosidase ( $\beta$-gal) & Food and dairy Industries & Patel et al. 1985; Furlan et al. 2000 \\
\hline Kojic acid & Antioxidant, whitening agent in cosmetics & Lobato et al. 2020 \\
\hline
\end{tabular}

3-hydroxy-3 methylglutaryl-coenzyme A responsible for inhibiting cholesterol biosynthesis (Hajjaj et al. 2005).

Contributions of $A$. oryzae have extended to the production of heterologous proteins, thanks to the prestigious secretion machinery owned by $A$. oryzae that allows it to secrete high concentrations of proteins into the culture medium (Machida, 2002). Neoculin is one of the important taste-modifying hetero-oligomeric proteins produced by A. oryzae (Nakajima et al. 2006). Moreover, human lysozyme, and recombinant antibodies (such as adalimumab) were also produced by $A$. oryzae in order to reduce their production costs (Huynh et al. 2020).

Due to its various industrial applications as well as its capability to produce high concentrations of proteins into the culture medium, A. oryzae has continuously attracted scientists' attention as a potent biotechnological tool that has potent contributions in industrial, food, veterinary, and pharmaceutical fields. In this review, the secondary metabolites produced by $A$. oryzae, and its use as a biotechnological tool for enzymes production were presented. Moreover, domestication, functional genomics, and using $A$. oryzae for functional production of human pharmaceutical proteins were highlighted. Finally, future prospects of getting more benefits from using A. oryzae were discussed.

\section{Morphology, and classification of $A$. oryzae}

A. oryzae belongs to Aspergillus flavus-oryzae group and its species can be differentiated according to their conidia shapes (Moubasher 1993; Elkhateeb 2005). A. oryzae belongs to Class: Eurotiomycetes; Order: Eurotiales; Family: Trichocomaceae. It is important to mention that molecular and genetic identification techniques usually fail to differentiate between the two fungi, A. oryzae and $A$. flavus, and eventually morphological and microscopic characteristics are the conclusive techniques used to identify $A$. oryzae. A. oryzae have the ability to grow on many media including, potato dextrose agar on which the growth is fast with heavy colonies, Czapek's agar on which colonies after 7 days at $25{ }^{\circ} \mathrm{C}$ attaining $7-8 \mathrm{~cm}$ in diameter with faintly yellowish margin shifting to yellow green similar to the growth obtained on malt extract agar. Generally, $A$. oryzae has an optimal growth, at temperature of $32-36{ }^{\circ} \mathrm{C}\left( \pm 1{ }^{\circ} \mathrm{C}\right)$ and it cannot grow above $44{ }^{\circ} \mathrm{C}$, in $\mathrm{pH}$ ranging between 5.0 , and 6.0 and it can germinate at $\mathrm{pH}$ from 2.0 to 8.0. A. oryzae could grow in corn flour with a water content of about 16\% (Moubasher 1993). Under microscope, A. oryzae is famous by its globose vesicle with elongated conidial chains, which look like fluffy-white strands on the substrate inhibited by $A$. oryzae (Moubasher 1993). A. oryzae conidiophores are long, arising from substrate, rough-walled, conidial head large, radiate (Fig. 1) with globose to subglobose conidia. A. oryzae has been isolated from soils and different plants such as rice, broad bean, sunflower, soybean, and wheat (Elkhateeb 2005).

\section{Secondary metabolites originated from $A$. oryzae and their bioactivities}

Besides its potent secretion machinery, A. oryzae is a generous source of various secondary metabolites as shown in Fig. 2. Those metabolites belong to different chemical classes such as terpenoids, coumarins, oxylipins, and fatty acids (Son et al. 2018). It is important to mention that secretion of secondary metabolites in A. oryzae (as in case of many other microorganisms) is significantly affected by different cultivation conditions. Many of the metabolites secreted by $A$. oryzae have different reported bioactivities such as anticancer, cytotoxicity, antimicrobial, antihypertensive, and antiviral activities (Table 2). 


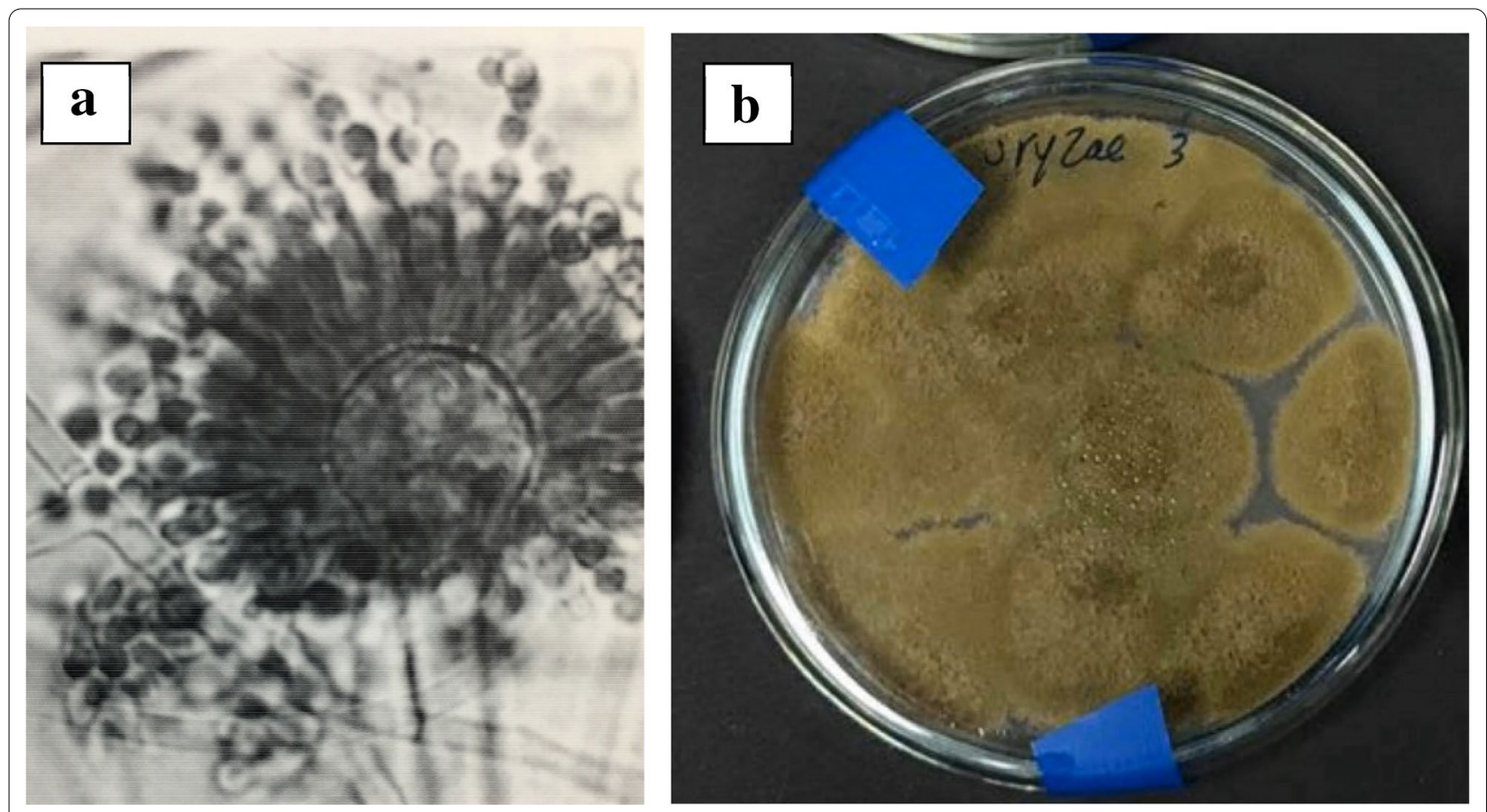

Fig. 1 Morphology of Aspergillus oryzae: A under microscope, B cultivated on potato dextrose agar medium

Isocoumarin derivatives produced by $A$. oryzae solid cultures exerted moderate anticancer activities against many human cancer cell lines (Zhou et al. 2016); the heterotetracyclic gliotoxin, aspirochlorine, exert antimicrobial and antifungal activities (Chankhamjon et al. 2015); aspergillic acids exhibit antihypertensive, and antifungal activities (Nishimura et al. 1991); the polyamino acid, aspergillomarasmine $\mathrm{A}$ is a rapid and potent inhibitor of the NDM-1 enzyme and another clinically relevant metallo- $\beta$-lactamase, and VIM- 2 . Aspergillomarasmine A contributed in fully restoring the effect of meropenem against many species of Enterobacteriaceae, Pseudomonas, and Acinetobacter (King et al. 2014). On the other hand, aspergillomarasmine $\mathrm{B}$ has antiangiogenic effect (He et al. 2019). Interestingly, a strain of A. oryzae was successfully generated to produce penicillin and the obtained strain showed over 100-fold over expression of $V e A$ which is important for penicillin production (Marui et al. 2010). Asperfuran is a dihydrobenzofuran derivative that exerts antifungal and anticancer activities (Pfefferle et al. 1990). Nevertheless, some mycotoxins have also been reported from $A$. oryzae, such as kojic acid which has various applications in cosmetics as whitening agent, has strong antibacterial and anti-tyrosinase activities, and also reported to have potential carcinogenicity (Burnett et al. 2010; Saeedi et al. 2019). Also, the indol tetrameric acid, cyclopiazonic acid, and $\beta$-nitropropionic acid were also reported as metabolites from A. oryzae (Blumenthal,
2004). Genetic manipulation is used to remove the biosynthetic gene cluster of cyclopiazonic acid in order to avoid its biosynthesis in biotechnological processes.

\section{A. oryzae as a biotechnological tool for industrial enzymes production}

Recently, there is a major scope for utilizing low and safe resources for valuable byproducts production. Employing enzymes from microbial origin in industrial applications are preferred over enzymes produced by conventional methods due to many reasons, such as their economic feasibility, low toxicity and being eco-friendly, their low energy demand, their better efficiency, and better quality products (Gurung et al. 2013). Moreover, the competence of microbes to be cultivated on solid substrates provides the possibility of converting agricultural byproducts into valuable materials helping in both sustainable agriculture and environmental conservation. Generally, microbial enzymes of fungal origin are more favorable due to fungal hyphal mode of growth and their good tolerance to low water activity (0.5-0.6 aw), and high osmotic conditions (Raimbault 1998; Raveendran et al. 2018). Enzymes production is conducted either by solid-state fermentation (SSF) or submerged fermentation (SmF) (Subramaniyam and Vimala 2012).

Since A. oryzae has GRAS status (Reichelt 1983), it is safely used as a source of many industrial enzymes as shown in Table 3. Liang et al. (2009) and 
Chancharoonpong et al. (2012) reported high quantities of hydrolytic enzymes in soybean koji inoculated with $A$. oryzae including amylase, neutral protease, alkaline protease, metallopeptidase, and glutaminase.

Proteases are a group of multifunctional enzymes that are tremendously applicable in food, pharmaceutical, medical, and biotechnological industries, accounting for about $60 \%$ of the complete enzyme market (Ramakrishna et al. 2010). Fungal proteases are characterized by their wide biochemical diversity, susceptible to genetic manipulation, high productivity, being extracellular, and hence can be easily recovered from fermentation medium (Silva et al. 2011). de Castro and Sato (2014) utilized $A$. oryzae protease produced on wheat bran by SSF for protein hydrolysis of soy protein isolate (SPI), bovine whey protein (BWP), and egg white protein (EWP) resulting in increasing natural antioxidant activity. Prolyl endopeptidase, is another enzyme that plays an important role in digestion of proline-rich proteins, can be used as an oral enzyme therapy product in patients affected by<smiles>O=c1cc(CO)occ1O</smiles>

Kojic acid<smiles>O=C(O)CC[N+](=O)[O-]</smiles>

3-nitropropionic acid<smiles>CON1C(=O)N[C@@H]2[C@@H](SS[C@@]23Oc2cc(O)c(Cl)cc23)C1=O</smiles>

Aspirochlorin

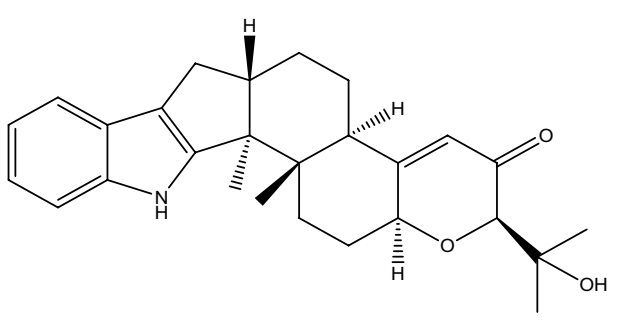

13-desoxypaxilline

Aspergillomarasmine A<smiles>C/C=C/C=C/[C@@]1(C)Cc2cc(O)cc(O)c2O1</smiles>

Asperfuran<smiles>C=C(C)[C@]12O[C@H]1[C@@]1(C)C(=CC2=O)CC[C@H](O)[C@@H]1C</smiles>

Sporogen AO1<smiles>COc1cc2ccoc(=O)c2c(O)c1O</smiles>

Dihydroxy-methoxycoumarin

Fig. 2 Some secondary metabolites produced by A. oryzae 
<smiles>CC(=O)CC(O)Cc1cc2cc(O)cc(O)c2c(=O)o1</smiles>

Ketone-citreoisocoumarin<smiles>C/C=C/CC(=O)c1c(O)ccc(O)c1O</smiles><smiles>O=C1c2cc(O)c(O)cc2C(=O)c2c1cc(O)c(O)c2O</smiles>

Pentahydroxy-anthraquinone<smiles>COc1c(O)cc2c(c1O)CN1C(=O)C(CC3CNc4ccccc43)NC(=O)C1C2</smiles>

Diketopiperazine derivative

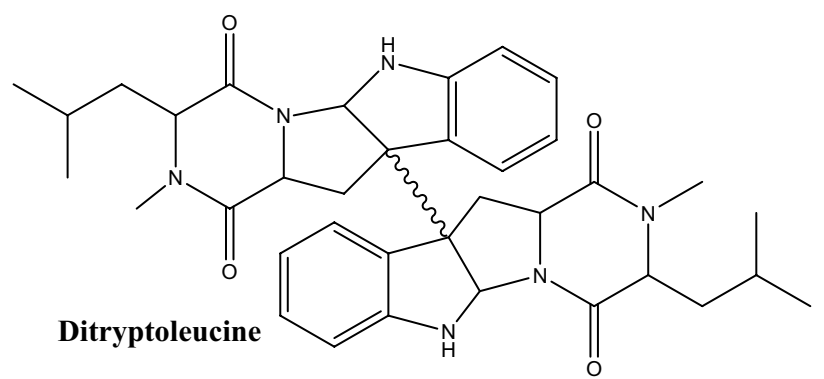<smiles>CC(=O)C1=C(O)[C@H]2[C@H]3C4=CCc5cccc(c54)C[C@H]3C(C)(C)N2C1=O</smiles>

Cyclopiazonic acid

Fig. 2 continued 
<smiles>CC(=O)N[C@@H](Cc1ccc(O)cc1)C(=O)N(C)C(CC(C)C)C(=O)N/C=C\c1c[nH]c2ccccc12</smiles>

Oryzamide A1-2

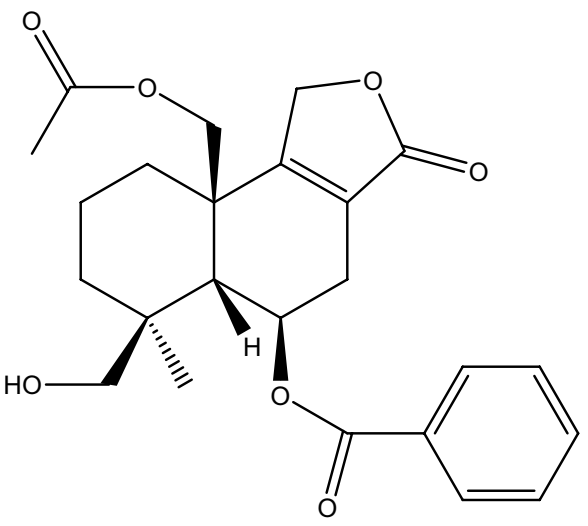

14-deacetyl parasiticolide A

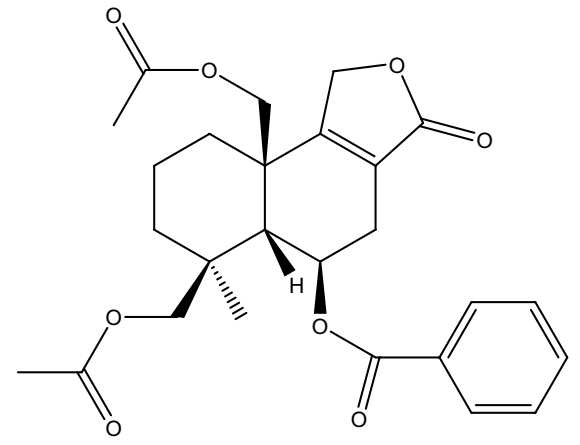

Parasiticolide A

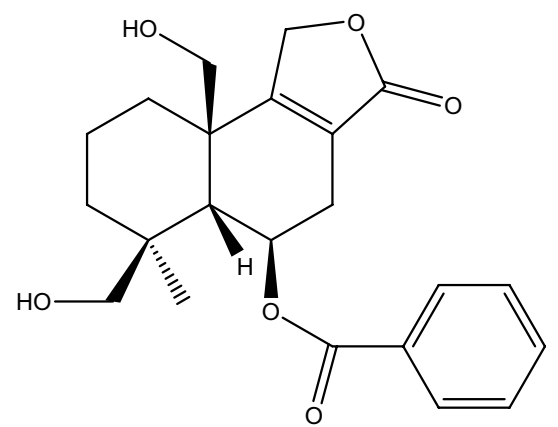

Dideacetyl parasiticolide A<smiles>CCC(C)c1cnc(CC(C)C)c(=O)n1O</smiles>

Aspergillic acid

Fig. 2 continued

intolerance to gluten (a group of proline-rich proteins found in wheat, rye and barley) and was reported to be produced by $A$. oryzae on wheat gliadin (Eugster et al. $2015)$. The amylases ( $\alpha$-amylases, $\beta$-amylases, and glucoamylases) are one of the very useful families of enzymes in biotechnology and have the widest range of industrial applications (Rodriguez et al. 2006). Alpha amylases (E.C. 3.2.1.1., 1,4- $\alpha$-D-glucan glucanohydrolase) catalyze hydrolysis of internal $\alpha-1,4$ glycosidic linkage in starch, amylopectin and amylose converting them into maltose and glucose. These enzymes are critically important especially in the detergent and the food industries (Brown 
Table 2 Some secondary metabolites produced by A. oryzae and their biological activities

\begin{tabular}{|c|c|c|c|}
\hline Metabolite & Chemical class & Bioactivity and uses & References \\
\hline Kojic acid & Carboxylic acid & $\begin{array}{l}\text { Antimicrobial, pain killer; antioxidant; flavor } \\
\text { enhancer, insecticide activator; has melano- } \\
\text { genes inhibitory activity; used in skin whitening, } \\
\text { and UV protecting products; used as iron } \\
\text { chelator }\end{array}$ & Mohamad et al. 2010; Saeedi et al. 2019 \\
\hline Glutamic acid & Carboxylic acid & $\begin{array}{l}\text { Protein synthesis; food additive and flavor } \\
\text { enhancer; anticancer agent }\end{array}$ & Dutta et al. 2013 \\
\hline L-Malate & Carboxylic acid & Used in food and beverage industries & Ji et al. 2021 \\
\hline Penicillin & $\beta$-lactam antibiotics & Antimicrobial agent & Marui et al. 2010 \\
\hline Isocoumarins & Lactones & Anticancer activities & Zhou et al. 2016 \\
\hline 3-Nitropropionic acid & Carboxylic acid & Neurotoxic; mitochondrial inhibitor & Geddes et al. 2000 \\
\hline Pyridoxine (vitamin $\mathrm{B}_{6}$ ) & Vitamin & $\begin{array}{l}\text { Treat or prevent vitamin } \mathrm{B}_{6} \text { deficiency; treat ane- } \\
\text { mia; prevent or treat a certain nerve disorder }\end{array}$ & Frisvad et al. 2018 \\
\hline Cyanocobalamine & Vitamin & Prevent and treat vitamin $\mathrm{B}_{12}$ deficiency & Sakai 1953; Ramakrishnan and Sathe 1956 \\
\hline Aspergillic acid & Carboxylic acid & Antimicrobial and antihypertensive agent & Nishimura et al. 1991 \\
\hline Mutaaspergillic acid & Carboxylic acid & Growth inhibitor against hiochi-bacteria & Nakamura 1960 \\
\hline Aspergillomarasmine A & Polyamino acid & Metallo- $\beta$-lactamase Inhibitor & Zhang et al. 2017a, b \\
\hline Aspirochlorin & Halogenated spiro compound & Antifungal and antibacterial activities & Rebollar-Pérez et al. 2019 \\
\hline Asperfuran & Dihydrobenzofuran & Antifungal and anticancer activities & Pfefferle et al. 1990 \\
\hline Tocopherols & Phenol & Antioxidant & Frisvad et al. 2018 \\
\hline Sporogen $\mathrm{AO} 1$ & Sesquiterpene & Antifungal, antimalarial activities & Dumas et al. 2017 \\
\hline Phomenone & Sesquiterpene & $\begin{array}{l}\text { Stimulate pro-inflammatory responses in murine } \\
\text { cells }\end{array}$ & Rand et al. 2017 \\
\hline
\end{tabular}

Table 3 Some industrial enzymes originated from A. oryzae and their substrates

\begin{tabular}{|c|c|c|c|}
\hline Enzyme & Substrate & Production yield & Reference \\
\hline Neutral protease & Soy bean & $84.38 \mathrm{U} / \mathrm{g}$ & Chancharoonpong et al. 2012 \\
\hline \multirow[t]{2}{*}{ Alkaline protease } & Soy bean & $41.35 \mathrm{U} / \mathrm{g}$ & Chancharoonpong et al. 2012 \\
\hline & Wheat bran & $600 \mathrm{U} / \mathrm{ml}$ & Ram and Kumar 2018 \\
\hline \multirow[t]{5}{*}{ a-amylase, glucoamylase } & Coconut oil cake & $3388 \mathrm{U} / \mathrm{g}$ & Ramachandran et al. 2004 \\
\hline & Soy bean & 200 U/g & Chancharoonpong et al. 2012 \\
\hline & Wheat bran & $1986 \mathrm{U} / \mathrm{g}$ & Zambare 2010 \\
\hline & Wheat bran & $36.31 \mathrm{U} / \mathrm{ml}$ & Lakshmi and Jyothi 2014 \\
\hline & Wheat bran and sugar cane bagasse & $330 \mu \mathrm{g} / \mathrm{ml} / \mathrm{min}$ & Parbat and Singhal 2011 \\
\hline Prolyl endopeptidases & Wheat gliadin & $22 \mathrm{U} / \mathrm{ml}$ & Eugster, et al., 2015 \\
\hline Cellulase & Corncobs & $38.80 \mathrm{U} / \mathrm{ml}$ & Sher et al. 2017 \\
\hline Asparaginase & Asparagine & $282 \mathrm{U} / \mathrm{ml}$ & Dias et al. 2016 \\
\hline Lipase & Sorghum & $35.66 \mathrm{U} / \mathrm{ml}$ & Ahmed et al. 2019 \\
\hline \multirow[t]{2}{*}{ Pectinase } & Soybean residue & $120 \mathrm{U} / \mathrm{ml}$ & Meneghel et al. 2014 \\
\hline & Cellulose & $2.03 \mathrm{U} / \mathrm{ml}$ & Ketipally and Raghu Ram 2018 \\
\hline$\beta$-galactosidase & Wheat bran and rice husk & $386.6 \mathrm{U} / \mathrm{ml}$ & Nizamuddin et al. 2008 \\
\hline
\end{tabular}

et al. 2013). Ramachandran et al. (2004) utilized different oil cakes which are the byproducts obtained after oil extraction, while Fadel et al. (2020) utilized wheat bran, corn flour, sugar beet pulp, sun flower for $\alpha$-amylase production by $A$. oryzae. Glucoamylases are generally used in high fructose corn syrup, glucose syrup, and alcohol production (James and Lee 1997; Biesebeke et al. 2005).
Lakshmi and Jyothi (2014) reported the ability of $A$. ory$z a e$ to secrete glucoamylase through growing on wheat bran. On the other hand, lipases, the triacylglycerol acyl hydrolases (EC 3.1.1.3) emulsify substrates and hydrolyze glycerides to free fatty acids and glycerols. Lipases are employed in the synthesis of many dairy products, oils and fats, many applications in detergents, cosmetics 
and medicine (Priji et al. 2016). Lipases are commonly applied in food products to enhance both aroma and flavor of cheese, yogurt, milk, and butter (Iftikhar et al. 2011). Ahmed et al. (2019) reported lipase production by $A$. oryzae on a variety of lignocellulolytic materials (wheat bran, sorghum, rice bran, wheat straw, corn cobs).

Cellulases and pectinases are responsible for hydrolyzing cellulose and pectin, respectively, into glucose. Cellulases are widely applicable in pollution treatment, animal feed, food, textile, protoplast production, genetic engineering, paper, fuel, and chemical industries (Bhat, 2000; Chen et al. 2012). Pectinase enzyme (EC. 3.2.1.15) is ranked as one of the highly important industrial enzymes that find its application in juice and beverage processing, vegetable oil extraction and other food industries (Pinheiro et al. 2017). Hoa and Hung (2013) reported the ability of $A$. oryzae to produce cellulase and pectinase on soybean residue.

$\beta$-galactosidase (EC 3.2.1.23), is also known as $\beta$-gal, that hydrolyzes lactose (milk sugar) into glucose and galactose, used for the improvement of milk and its derivatives for consumption by people with lactose intolerance, for prevention of crystallization of lactose in frozen and condensed milk products and also for the increase of the sweetening properties of lactose (Patel et al. 1985; Furlan et al. 2000). Nizamuddin et al. (2008) utilized wheat bran and rice husk as solid substrates for $\beta$-galactosidase production. Asparaginase is also another enzyme produced by $A$. oryzae, and is responsible for catalyzing asparagine hydrolysis into ammonia and aspartic acid (Olempska-Beer 2007).

\section{Genomics, safety, and domestication of $A$. oryzae}

Generally, strains belonging to this species show variety in color and fermentation potency. However, the relationship between the capabilities of $A$. oryzae different strains and genetic factors remains not well-studied. The first report describing the whole-genome sequencing of A. oryzae RIB40 was published by Japanese scientists in 2005 using whole-genome shotgun approach (Machida et al. 2005). The reported 37-Mb genome was predicted to carry 8 chromosomes, comprising 12,074 genes, and encoding proteins with more than one hundred amino acid residues. Conducting comparative genomic analysis of the whole genome sequences of Aspergillus fumigatus and Aspergillus nidulans showed that $A$. oryzae genome was larger than that of both mentioned species by 7-9 Mb (about 34 and 29\% larger genome sizes, respectively) (Galagan et al. 2005). Previously, it was suggested that the genes in newly acquired regions are only insignificantly expressed under normal conditions (Kobayashi et al. 2007) and most of their functions are still unidentified, especially for those genes not directly involved in fermentation. However, recently it was reported that the unique genes principally encode secretory hydrolases, stress responses, and metabolism (He et al. 2018a). One of the good databases concerned with protein as well as gene sequences of major Aspergillus species including A. oryzae, is the Aspergillus Genome Database (AspGD; www. aspgd.org). In this website, besides information about $A$. oryzae, analysis tools, and manually curated data derived from published scientific articles for $A$. nidulans, A. fumigatus, and A. niger (Arnaud et al. 2010). However, this informative website needs to be updated. It should be mentioned that according to many comparative analyses, $A$. flavus and $A$. oryzae genomes showed $99.5 \%$ similarity in coding regions and hence are regarded as genetically very closely related species. Previously, A. oryzae has been distinguished from A. flavus based on morphological characteristics and toxicity (Klich 2007; Jørgensen 2007), but recently a new molecular method was suggested to distinguish between both species based on conducting genome-wide total singlenucleotide polymorphisms (Chang 2019). Contrary to A. oryzae, some strains belonging to the genus $A$. flavus shows serious safety hazards due to their aflatoxin production ability (Kumar et al. 2017; Ezekiel et al. 2019). Interestingly, some $A$. oryzae strains contain all or parts of the biosynthetic gene cluster responsible for aflatoxin production, though they are non-aflatoxigenic (Kusumoto et al. 2000; Chang 2019). In a previous comparative study, A. oryzae was found to form a monophyletic clade derived from one clade of $A$. flavus. This was concluded based on phylogenetic analysis that was conducted on 11 genes, aflatoxin gene cluster and single-nucleotide polymorphism of the whole A. oryzae genome (Geiser et al. 1998; Chang et al. 2006). Although it was believed that both $A$. oryzae, and $A$. flavus have no sexual reproduction, genome analysis along with some recent studies showed that $A$. flavus can perform sexual reproduction. Moreover, both species contain an approximately complete gene set essential for sexual reproduction (Geiser et al. 1996; Wada et al. 2012). All strains of A. oryzae and A. flavus have one mating type (MAT type) locus in their genome, at which either MAT1-1 or MAT1-2 is encoded (Ramirez-Prado et al. 2008; Wada et al. 2012). Nevertheless, full sexual reproduction has not been confirmed in A. oryzae, and crossbreeding trials failed (Watarai et al. 2019). It was proposed by genome analysis that recombination happened among $A$. oryzae ancestors based on the disequilibrium in linkage between MAT types and a single gene phylogeny (Chang and Ehrlich 2010).

Development of the technology of third-generation sequencing has speeded the progress of genome projects concerned by $A$. oryzae, thanks to the long reads ability of this technology, which can improve genome 
annotation quality by reducing genome errors in assembly. Till now, the whole genome of about 10 strains of $A$. oryzae was deposited in NCBI database with genome sizes ranging between 35.42 and $41.16 \mathrm{Mb}$, and $\mathrm{GC}$ content of approximately $48 \%$ in most strains (He et al. 2018b). Fungal genomics is in its early stages for the breeding of industrial strains, in spite of the decoded genomes of numerous $A$. oryzae strains. Out of more than 10,000 genes, only about 200 genes (accounting for $1.7 \%$ of the whole genome) are functionally verified ( $\mathrm{He}$ et al. 2018b, 2019).

Domestication of microorganisms in general and of $A$. oryzae in particular is attracting the attention of current researchers. Domestication is simply concerned with wild species artificial selection and breeding in order to obtain cultivated variants that fulfill human or industrial needs (Steensels et al. 2019). Domestication of microorganisms has been highly appreciated in industrial fields especially in fermentation of beverage and food. Throughout domestication process, microorganisms acquire the ability to consume particular nutrients in an efficient way, survive the specific stress during industrial process, and produce desirable compounds. Interestingly, various lineages of the same species are adapted to highly varied niches, which results in phenotypically and genetically different strains (Steensels et al. 2019). Domestication is of $A$. oryzae includes selecting strains characterized by rapid mycelial growth, pleasing fragrances, high amylases yield, and low production of toxins or pigments. In a recent study, whole-genome sequencing was conducted on 82 industrial $A$. oryzae strains to determine their draft genomes. It was suggested that $A$. oryzae strains have passed by multiple intergenomic recombination events between ancestors of $A$. oryzae without any appearance of sexual recombination throughout the process of domestication, and that domestication of A. oryzae is tremendously limited to intra-genomic mutation and rearrangements (Watarai et al. 2019). Moreover, conducted intra- and inter-cladal comparative study revealed that nonsynonymous, gap mutations, and intra-genomic recombination were caused by the evolutionary pressure of domestication in a selective way. The strong ability of A. oryzae to produce different hydrolytic enzymes nominates it as a perfect model for the research of protein secretion and gene expression (Machida et al. 2005; He et al. 2019). Nevertheless, functional genomics progress in the field of $A$. oryzae remains limited due to the small number of available selection markers for A. oryzae, which are not amenable to traditional genetic manipulation measures (Zhong et al. 2018). Hence, exploiting effective genetic transformation and selection markers techniques is of great importance.

\section{Strategies for $\boldsymbol{A}$. oryzae functional genomics}

Different strategies reemployed in order to investigate functional genomic as shown in Table 4 and Fig. 3, including the use of selection markers, conducting transformations, and genetic manipulations (Mei et al. 2019; He et al. 2019).

\section{Selection markers strategy}

Starting with the effective selection markers which can reduce both false-positive rates as well as screening workload, the most commonly employed selection markers are drug resistance markers and auxotrophic markers. The drug resistance markers can be used as dominant selection markers, and for those markers no need that host strain be auxotrophic. After vector transformation with drug resistance genes, the host strain is able to grow in presence of specific concentrations of that drug. However, many disadvantages are facing the use of this technique such as the need for expensive antibiotics, and the high native drug resistance nature of $A$. oryzae resulted in a very few number of foreign hetero gene markers that can successfully be used as markers (Zhong et al. 2018; Miura et al. 2018). Moreover, some resistance genes can be transferred to the environment and other microbes, which is risky. For $A$. oryzae genetic transformation, some resistance genes such as hygromycin B resistance gene $(h p h)$ and $(h y g r)$, are examples of commonly used drug resistance markers. Interestingly, by using $h p h$ as a selection marker, scientists have succeeded in constructing an interference vector for $A$. oryzae and repressing the $w A$ gene expression which is involved in spores coloring (Fernandez et al. 2012). Also, the bleomycin resistance marker has also been employed in $A$. oryzae transformation through increasing $A$. oryzae susceptibility to bleomycin (Suzuki et al. 2009). Similarly, phleomycin and pyrithiamine resistance genes have been used for $A$. oryzae transformation as dominant selection markers (Zhang et al. 2017a, b). Anyway, due to the disadvantages of using drug resistance markers, FDA has forbidden using such markers in food-related microorganisms such as A. oryzae (Newsome et al. 2009). On the other hand, using auxotrophic markers as selection markers for screening is suitable and effective, based on selective culture media, transformation systems for $A$. oryzae was mainly improved according to auxotrophic markers for auxotrophic mutant strains complementation. After vector transformation with the corresponding auxotrophic marker, the resulting auxotrophs have similar phenotype with the wild type. The gene pyrG encoding for orotidine-5'-monophosphate (OMP) decarboxylase, which is a key enzyme for the biosynthesis of uridine/uracil that is important for fungal survival, and 


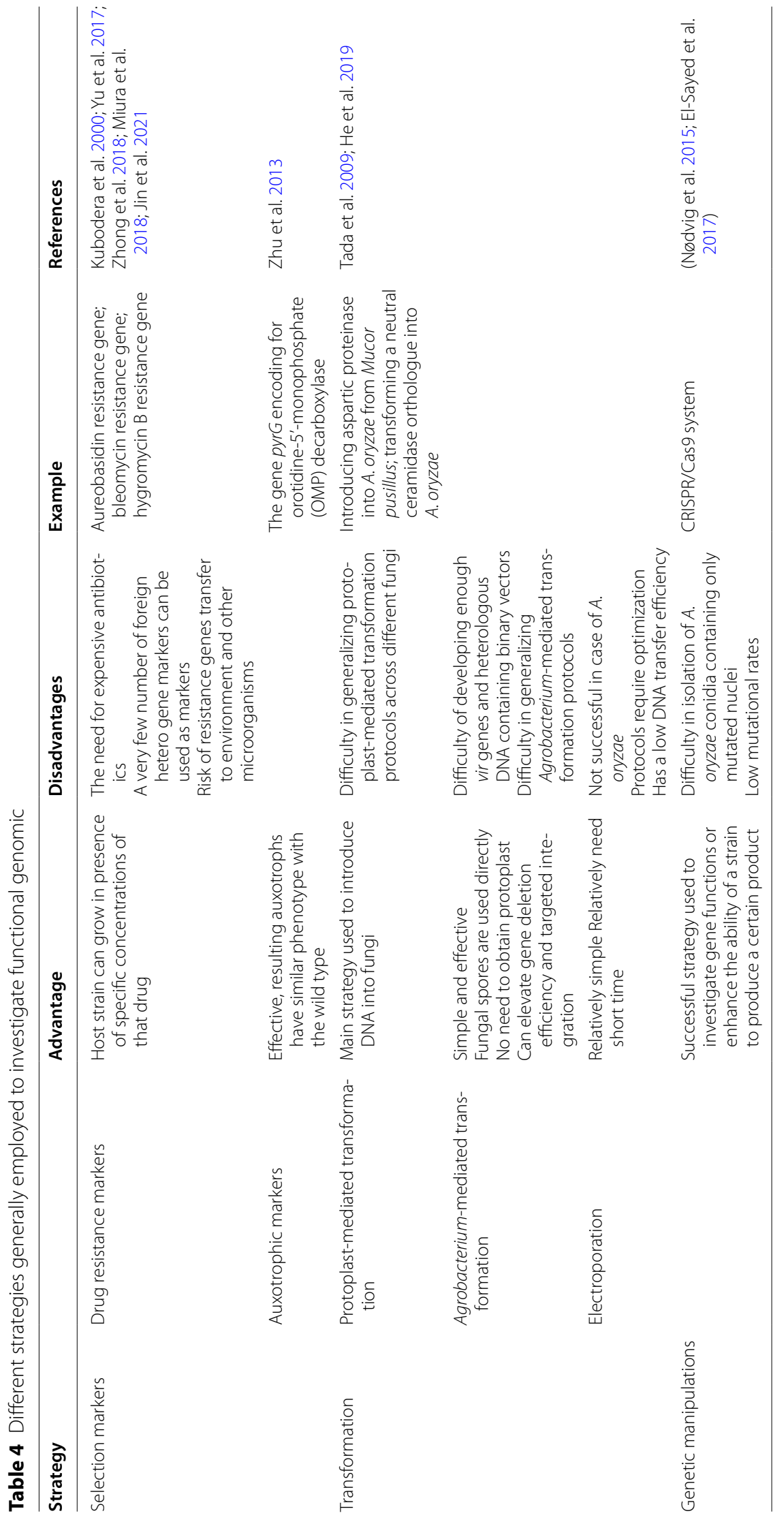




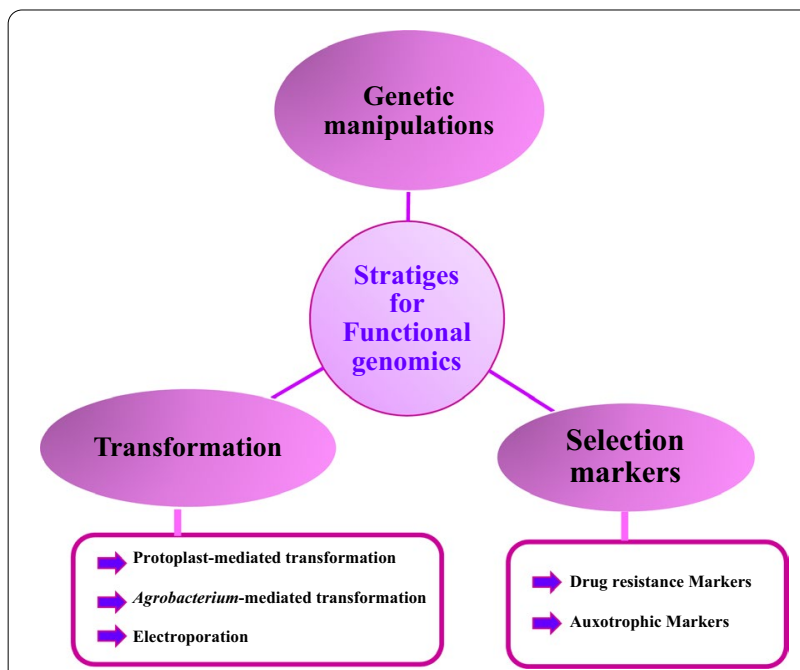

Fig. 3 Efficient strategies for fungal transformation conducted for functional genomic investigation

hence the pyrG mutants fail to convert orotidine into uridine and require additional supplementation of uridine or uracil for their growth (Zhu et al. 2013). For $A$. oryzae genetic transformation, pyrG is considered as the most commonly employed marker. A gene knockout system was developed using $A$. oryzae KBN630 as an original strain, and pyrG as a selection marker (YoshinoYasuda et al. 2011). Also, it was proven that the pyrG marker is a potent tool for recombinant gene expression investigations and genetic transformation concerned with A. oryzae (Nguyen et al. 2017). Moreover, multiple genes were disrupted and knocked out through a pyrG selectable marker (Maruyama and Kitamoto 2008; Yoon et al. 2011). Other nutritional markers were also investigated for $A$. oryzae transformation systems such as adeA for adenine, aopex11-1 which is involved in peroxisome proliferation, niaD for nitrate assimilation, or $\arg B$ for arginine biosynthesis (Jin et al. 2004a, 2004b; He et al. 2019).

\section{Transformations strategy}

The second group of strategies employed to investigate functional genomic are those conducted for transformation of $A$. oryzae. The low A. oryzae transformation efficiency represents the key obstacle to its successful genetic transformation (Jiang et al. 2013). Hence, to overcome this problem, researches employed different transformation techniques including protoplast-mediated transformation (which is the main strategy to introduce DNA into fungi due to the easiness of obtaining homozygotes), Agrobacterium-mediated transformation, and electroporation.

\section{Protoplast-mediated transformation}

This strategy is the main strategy used to introduce DNA into fungi due to the easiness of obtaining homozygotes. Examples for protoplast-mediated transformation are introducing an aspartic proteinase into A. oryzae from Mucor pusillus using niaD gene as selective marker; transforming a neutral ceramidase orthologue into $A$. oryzae (Tada et al. 2009). Due to the variation in composition of cell wall and potential fungal defense mechanisms, it is difficult to generalize protoplast-mediated transformation protocols across different fungi (Van den Berg et al. 2015). Accordingly, the procedure used for protoplast-mediated transformation of $A$. oryzae is a modified version, where preparation of protoplast is the main step that requires cell wall removing by cell walllytic enzymes or other mechanical non-enzymatic methods (Wang et al. 2017). Consequently, the transformation rate in filamentous fungi is principally affected by the efficiency of cell wall-degrading enzymes (Kück and Hoff 2010).

\section{The Agrobacterium-mediated transformation strategy}

Agrobacterium-mediated transformation is another simple and more efficient approach for targeting gene in $A$. oryzae. Thanks to the direct use of fungal spores, and the fact that obtaining protoplasts become not necessary, which is hard and relatively difficult. Moreover, the Agrobacterium-mediated transformation method can elevate gene deletion efficiency and targeted integration in some fungal genera when compared with other transformation methods. The Agrobacterium-mediated transformation strategy was traditionally used in plants, but now it is applied to yeast and filamentous fungi (Wang et al. 2014; Nguyen et al. 2016; Li et al. 2017). The reason for using the Gram-negative bacterium, Agrobacterium tumefaciens, is due to its ability to transfer the T-DNA region of the Ti plasmid to the infected plant genome. This method was successfully employed for transforming fungal spores, mycelia, and germlings (Govender and Wong 2017). There are some disadvantages for using Agrobacterium-mediated transformation such as the difficulty of developing enough vir genes and heterologous DNA containing binary vectors. Also due to the difficulty in generalizing Agrobacterium-mediated transformation protocols across different fungi because of the variable parameters controlling Agrobacterium-fungi conjugation and affecting rate of transformation.

\section{Electroporation strategy}

The third technique of transformation is electroporation, where a high-voltage electric pulse is applied to protoplasts and DNA containing solution. Although 
electroporation of protoplasts has been conducted for several yeasts and fungi, researchers have failed to transform A. oryzae through electroporation (Timofeev et al. 2019; Lichius et al. 2020). Therefore, there are no studies reported on conducting $A$. oryzae transformation using electroporation methods. Generally, electroporation protocols require optimization among different fungal species and are relatively difficult. Additionally, although electroporation is relatively simple and need relatively short time, it has a low DNA transfer efficiency $\left(\sim 1-5 \times 10^{4}\right.$ colonies/ $\left.\mu \mathrm{g}\right)$ in comparison with protoplast-mediated transformation (1 transformant per $10^{5}$ spores) and Agrobacterium-mediated transformation (10 transformants per $10^{5}$ spores) methods (Kotnik et al. 2015).

\section{Genetic manipulations}

Besides selection markers, and transformation strategies discussed before, genetic manipulations is a successful strategy used to investigate gene functions or enhance the ability of a strain to produce a certain product (Son and Park 2020; Ullah et al. 2020). To do so, it is important to generate a host with effective selection markers and high transformation rate. Till now, few attempts had been performed to manipulate genes in A. oryzae. For instance, highly branched mutants were generated by UV or nitrous acid mutagenesis (Bocking et al. 1999). Also, a novel food-grade industrial koji molds were bred with high acid protease activity by interspecific genome recombination between $A$. oryzae and $A$. niger (Xu et al. 2011). Furthermore, an RNAi system was constructed for gene silencing in A. oryzae using the Gateway system and compatible restriction enzyme sites to create the hairpin RNA cassette (Yamada et al. 2007). Recently, CRISPR/ Cas9 bacterial and archaeal immune mechanism was engineered into a simple, efficient, and powerful gene editing system, which contained only two components: the Cas9 nuclease and a single guide RNA (sgRNA). The CRISPR/Cas9 system has been successfully adapted to filamentous fungi such as Aspergillus aculeatus, Aspergillus fumigatus, and A. oryzae (Nødvig et al. 2015; ElSayed et al. 2017). However, difficulty in isolation of $A$. oryzae conidia containing only mutated nuclei, and the low mutational rates represent obstacles against using this system for genome editing used in A. oryzae (Katayama et al. 2016). The procedure of CRISPR/Cas9 system starts with optimizing codon usage of cas9 then inserted into the expression vector. After that, a promoter is fused with the sgRNA sequence and inserted into the expression vector containing cas9. A CRISPR/Cas9 system in $A$. oryzae was developed to knock out $w A$ (polyketide synthase), pyrG, and $y A$ (p-diphenol oxidase) (Katayama et al. 2016).

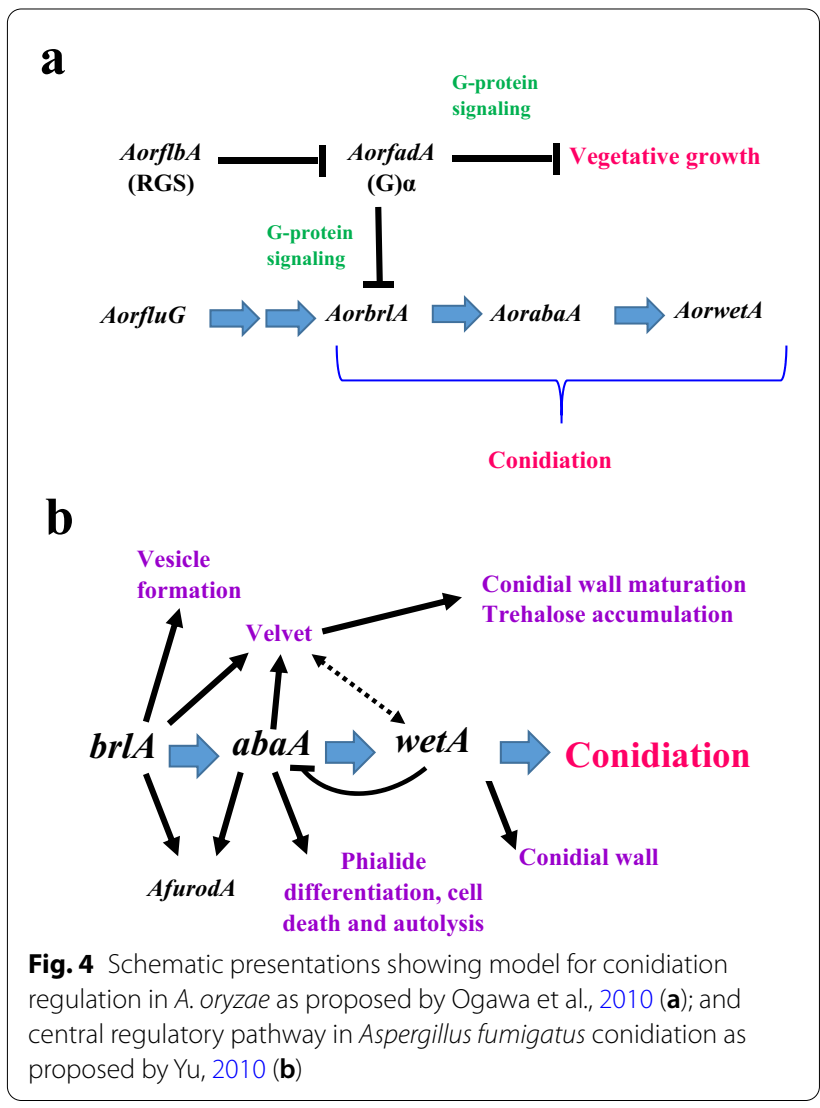

\section{Functional genomics for improving $A$. oryzae industrial application}

In order to improve A. oryzae for industrial applications, the functional genomics of $A$. oryzae can be employed mainly on conidiation, protein secretion and expression, and secondary metabolites.

\section{Regulation of conidiation process}

Conidiation is the process of producing conidia in conidiophores (Kitamoto 2015). The conidia of $A$. oryzae are important for the food industry as starters that digest ingredients in the first step of fermentation (Ogawa et al. 2010). Hence, conidiation regulatory pathway has attracted researchers' attention. Generally, conidiation process is putatively induced by external or internal signals that result in activation of a genetically programed sporulation (Murthy et al. 2018). Conidiation is induced when nutrients (carbon and nitrogen sources) are poorly available in culture medium (Krijgsheld et al. 2013). The regulatory mechanism of conidiation has been wellstudied in $A$. nidulans, and many studies have reported that the regulatory mechanisms are conserved between $A$. nidulans and A. oryzae, and that A. oryzae, A. nidulans, and A. fumigatus have a G-protein signaling pathway and $b r l A$ orthologs in common. Moreover, the 
analyses of AorflbA disruptant and AorfadA dominantactive mutants implicated that AorFadA-mediated G-protein signaling suppresses vegetative growth of $A$. oryzae as illustrated in Fig. 4a (Ogawa et al., 2010). Till now, $B r l A$ is the most well-studied conidiation regulatory gene. BrlA triggers a central regulatory pathway (Fig. 4b) regulating conidiation-specific genes expression such as abaA, medA, stuA, vosA, and wetA (Park et al. 2019). BrlA disruptants of $A$. oryzae failed to form conidiophores. On the other hand, the fadA G-protein-dependent signaling pathway also regulates conidiation by suppressing $\mathrm{brlA}$ activation. The Fad-mediated signaling is regulated by FlbA, which is a specific regulator of G-protein signaling. In $A$. oryzae, the fadA mutant is responsible for reducing intrinsic GTPase activity and causes formation of autolytic phenotypes. Furthermore, the overexpression of Rim15p (a serine-threonine kinase) in A. oryzae caused reduction in conidiation process which is completely stopped when Rim15p is deleted (Nakamura et al. 2016).

\section{Protein and secondary metabolites secretion and expression}

Being listed as GRAS by the FDA, and due to its potent secretion machinery, A. oryzae is an excellent host for industrial protein production such as amylases, chymo$\sin$, glucose oxidases, cellulases, lipases, pectinases, catalases, proteases, phytases, and xylanases in food (He et al. 2018a; Ntana et al. 2020). As a result, A. oryzae has been attracting continuous attention as a host for expressing homologous and heterologous proteins. Nevertheless, heterologous eukaryotic proteins are usually inefficiently produced compared to endogenous proteins. Till now, numerous obstacles have been reported and solved in the heterologous protein production process. Firstly, the most important factors are effective selection markers and effective $A$. oryzae transformation strategies, which have been described previously. Secondly, presence of secreted proteases with their proteolytic degradable abilities in the culture medium is considered as another serious obstacle in heterologous protein production (Yokota et al. 2017). To overcome this proteolytic degradation, scientists have constructed multiple protease gene disruptants, which increased the heterologous proteins yields (Yoon et al. 2011; Hoang et al. 2015). Moreover, a significant improvement of heterologous protein production by $A$. oryzae is accomplished by repressing autophagy genes and vacuolar protein sorting (VPS), which play key roles in the secretory pathway (Yoon et al. 2010). Furthermore, the yield of heterologous proteins was improved through genetic fusion of a target protein with endogenous carrier proteins which are usually secreted enzymes (Yoon et al. 2010). In transcription and posttranscriptional processes, heterologous fusion protein technique can improve yields. The approach of fusion proteins was recently developed to increase heterologous protein expression through the modulation of endoplasmic reticulum-Golgi cargo receptors (Hoang et al. 2015). The carrier-fused heterologous proteins secretion can be affected by lectin-type cargo receptors and hence improve heterologous protein production.

Comparing the $A$. oryzae genome with those of $A$. fumigatus and $A$. nidulans revealed that extra genes are predominantly involved into secretory hydrolases, transporters, and secondary metabolites production genes. Generally, secondary metabolites are synthesized by gene clusters, most of which encode typical backbone enzymes, such as non-ribosomal peptide synthase and polyketide synthase. The $A$. oryzae genome contains 56 gene clusters, from which only 14 genes are identified as biosynthetic gene cluster involved in production of kojic acid. These genes include an enzyme gene (kojA), $\mathrm{Zn}(\mathrm{II}) 2 \mathrm{Cy} 6$ transcription factor gene $(k o j R)$, and a transporter gene (kojT) (Yamada et al. 2014). The safety of $A$. oryzae can be explained by the lack of the aflR gene which made $A$. oryzae cannot produce aflatoxins (Lee et al. 2014).

\section{Functional production of human pharmaceutical proteins using $A$. oryzae}

$A$. oryzae has been nominated as a promising host for production of heterologous proteins from different high eukaryotes due to its ability to secrete high concentrations of proteins into the culture medium (Machida 2002). Furthermore, using A. oryzae for the production of the heterooligomeric protein, neoculin, which has taste-modifying activity was also reported (Nakajima et al. 2006).Tsuchiya et al. in (1992) have reported production of active human lysozyme from $A$. oryzae transformants through expression of the introduced mature human lysozyme (HLY gene). Moreover, the great demand together with the requirement for reducing cost of antibodies has attracted serious attention in order to find a suitable expression platform for producing recombinant antibodies. In a recent study, $A$. oryzae was employed for the production of adalimumab, which is an antibody (IgG) that binds in a specific way to the inflammatory cytokine, human TNF $\alpha$. Adalimumab has been used in the treatment of some chronic inflammatory diseases such as rheumatoid arthritis. Production of adalimumab was successfully conducted in the culture supernatant of $A$. oryzae transformants with comparable affinities and bioactivities to its commercial counterpart (Huynh et al. 2020). 


\section{Conclusion and future prospects}

Due to its various applications in food, veterinary, and pharmaceuticals industries, A. oryzae is considered as a potent biotechnological tool of great interest. Recent advances in techniques such as next-generation sequencing has improved the research on the functional genomics of this valuable fungus, which is helpful to the genetic enhancement of $A$. oryzae fermentative strains. Coupling of protoplast-mediated transformation along with Agrobacterium-mediated transformation will contribute in enhancing transformation process. Discovering new strategies, and optimization of current strategies used for functional genomics of $A$. oryzae will be helpful for getting maximum benefits from $A$. oryzae in order to be employed in industrial production. Finally, updating and developing current websites, and creating new open access websites carrying recent literature about $A$. oryzae is of great importance. Such tools can facilitate researchers work and keep them updated with recent available data concerning this industrially important koji mold.

\section{Acknowledgements}

Not applicable.

\section{Authors' contributions}

All authors read and approved the final manuscript.

\section{Funding}

This research received no specific grant from any funding agency in the public, commercial, or not-for-profit sectors,

\section{Availability of data and materials}

Not applicable.

\section{Declarations}

Ethics approval and consent to participate

Not applicable.

\section{Consent for publication}

Not applicable.

\section{Competing interests}

The authors declare that they have no competing interests.

Received: 17 April 2021 Accepted: 16 June 2021

Published online: 22 June 2021

\section{References}

Ahmed A, Badar R, Khalique N (2019) Screening and optimization of submerged fermentation of lipolytic Aspergillus oryzae. BioResources 14(4):7664-7674

Arnaud MB, Chibucos MC, Costanzo MC, Crabtree J, Inglis DO, Lotia A, Orvis J, Shah P, Skrzypek MS, Binkley G, Miyasato SR, Wortman JR, Sherlock G (2010) The Aspergillus Genome Database, a curated comparative genomics resource for gene, protein and sequence information for the Aspergillus research community. Nucleic Acids Res 38:D420-427

Barbesgaard P, Heldt-Hansen HP, Diderichsen B (1992) On the safety of Aspergillus oryzae: a review. Appl Microbiol Biotechnol 36:569-572

Bhat MK (2000) Cellulases and related enzymes in biotechnology. Biotechnology Advance 18:355-383
Biesebeke R, Record E, van Biezen N, Heerikhuisen M, Franken A, Punt PJ, van den Hondel CA (2005) Branching mutants of Aspergillus oryzae with improved amylase and protease production on solid substrates. Appl Microbiol Biotechnol 69:44-50

Blumenthal CZ (2004) Production of toxic metabolites in Aspergillus niger, Aspergillus oryzae, and Trichoderma reesei: Justification of mycotoxin testing in food grade enzyme preparations derived from the three fungi. Regul Toxicol Pharmacol 39:214-228

Bocking SP, Wiebe MG, Robson GD, Hansen K, Christiansen LH, Trinci AP (1999) Effect of branch frequency in Aspergillus oryzae on protein secretion and culture viscosity. Biotechnol Bioeng 65(6):638-648

Brown I, Dafforn T, Fryer P, Cox P (2013) Kinetic study of the thermal denaturation of a hyper thermostable extracellular $a$-amylase from Pyrococcus furiosus. Biochim Biophys Acta 1834(12):2600-2605

Burnett CL, Bergfeld WF, Belsito DV, Hill RA, Klaassen CD, Liebler DC, Marks JG, Shank RC, Slaga TJ, Snyder PW, Andersen FA (2010) Final report of the safety assessment of kojic acid as used in cosmetics. Int J Toxicol 29(6 suppl):244S-273S

Chancharoonpong C, Hsieh PC, Sheu SC (2012) Enzyme production and growth of Aspergillus oryzae S. on soybean koji fermentation. APCBEE Proc 2:57-61

Chang PK (2019) Genome-wide nucleotide variation distinguishes Aspergillus flavus from Aspergillus oryzae and helps to reveal origins of atoxigenic $A$. flavus biocontrol strains. J Appl Microbiol 127(5):1511-1520

Chang PK, Ehrlich KC (2010) What does genetic diversity of Aspergillus flavus tell us about Aspergillus oryzae? Int J Food Microbiol 138:189-199

Chang PK, Ehrlich KC, Hua S-S (2006) Cladal relatedness among Aspergillus oryzae isolates and Aspergillus flavus S and L morphotype isolates. Int J Food Microbiol 108:172-177

Chang, P. K., Horn, B. W., Abe, K., Gomi, K. 2014. Aspergillus: introduction. In Encyclopedia of Food Microbiology, 2nd Edition. Elsevier Inc; 77-82. https://doi.org/10.1016/B978-0-12-384730-0.00010-0

Chankhamjon P, Boettgerschmidt D, Scherlach K, Urbansky B, Lackner G, Kalb D, Dahse HM, Hoffmeister D, Hertweck C (2015) Biosynthesis of the halogenated mycotoxin aspirochlorine in koji mold involves a cryptic amino acid conversion. Angew Chem 53:13409-13413

Chen Y, Wan J, Zhang X, Ma Y, Wang Y (2012) Effect of heating on recycled properties of unbleached eucalyptus cellulose fiber. Carbohyd Polym 87:730-736

Christensen T, Woeldike H, Boel E, Mortensen SB, Hjortshoej K, Thim L, Hansen MT (1988) High level expression of recombinant genes in Aspergillus oryzae. Biotechnol 6:1419-1422

Dawood MA, Eweedah NM, Khalafalla MM, Khalid A (2020) Evaluation of fermented date palm seed meal with Aspergillus oryzae on the growth, digestion capacity and immune response of Nile tilapia (Oreochromis niloticus). Aquac Nutr 26(3):828-841

de Castro RJ, Sato HH (2014) Protease from Aspergillus oryzae: biochemical characterization and application as a potential biocatalyst for production of protein hydrolysates with antioxidant activities. J Food Process. https://doi.org/10.1155/2014/372352

Dias FFG, Ruiz ALTG, Della Torre A, Sato HH (2016) Purification, characterization and antiproliferative activity of L-asparaginase from Aspergillus oryzae CCT 3940 with no glutaminase activity. Asian Pacific JTrop Biomed 6:785-794

Dumas F, Kousara M, Chen L, Wei L, Le Bideau F (2017) Nonhalogenated heterotricyclic sesquiterpenes from marine origin i: fused systems. Studies Nat Products Chem 52:269-302

Dutta S, Ray S, Nagarajan K (2013) Glutamic acid as anticancer agent: an overview. Saudi Pharma J 21:337-343

Elkhateeb, W.A., 2005. Some mycological, phytopathological and physiological studies on mycobiota of selected newly reclaimed soils in Assiut Governorate, Egypt (M. Sc. Thesis, Faculty of Science, Assuit University, Egypt). p 238.

El-Sayed AS, Abdel-Ghany SE, Ali GS (2017) Genome editing approaches: manipulating of lovastatin and taxol synthesis of filamentous fungi by CRISPR/Cas9 system. Appl Microbiol Biotechnol 101(10):3953-3976

Eugster PJ, Salamin K, Grouzmann E, Monod M (2015) Production and characterization of two major Aspergillus oryzae secreted prolyl endopeptidases able to efficiently digest proline-rich peptides of gliadin. Microbiology 161:2277-2288 
Ezekiel CN, Ortega-Beltran A, Oyedeji EO, Atehnkeng J, Kössler P, Tairu F, Hoeschle-Zeledon I, Karlovsky P, Cotty PJ, Bandyopadhyay R (2019) Aflatoxin in chili peppers in Nigeria: extent of contamination and control using atoxigenic Aspergillus flavus genotypes as biocontrol agents. Toxins 11(7):429

Fadel M, AbdEl-Halim S, Sharada H, Yehia A, Ammar M (2020) Production of glucoamylase, a-amylase and cellulase by Aspergillus oryzae F-923 Cultivated on wheat bran under solid state fermentation. J Adv Biol Biotech 23(4):8-22

Fernandez EQ, Moyer DL, Maiyuran S, Labaro A, Brody H (2012) Vector-initiated transitive RNA interference in the filamentous fungus Aspergillus oryzae. Fungal Genet Biol 49(4):294-301

Frisvad JC, Møller LL, Larsen TO, Kumar R, Arnau J (2018) Safety of the fungal workhorses of industrial biotechnology: update on the mycotoxin and secondary metabolite potential of Aspergillus niger, Aspergillus oryzae, and Trichoderma reesei. Appl Microbiol Biotechnol 102:9481-9515

Furlan SA, Schneider A, Merkle R, Jonas M, Jonas R (2000) Formulation of a lactose-free, low-cost medium for the production of $\beta$-galactosidase by Kluyveromyces marxianus. Biotech Lett 22:589-593

Galagan JE, Calvo SE, Cuomo C, Ma LJ, Wortman JR, Batzoglou S, Lee SI, Baştürkmen M, Spevak CC, Clutterbuck J, Kapitonov V (2005) Sequencing of Aspergillus nidulans and comparative analysis with A. fumigatus and A. oryzae. Nature 438(7071):1105-1115

Geddes JW, Bondada V, Pang Z (2000) Mechanisms of 3-nitropropionic acid neurotoxicity. In: Sanberg PR, Nishino H, Borlongan CV (eds) Mitochondrial inhibitors and neurodegenerative disorders. Humana Press, Totowa, pp 107-120

Geiser DM, Timberlake WE, Arnold ML (1996) Loss of meiosis in Aspergillus. Mol Biol Evol 13:809-817

Geiser DM, Pitt JI, Taylor JW (1998) Cryptic speciation and recombination in the aflatoxin-producing fungus Aspergillus flavus. Proc Natl Acad Sci USA 95:388-393

Gomi K (2019) Regulatory mechanisms for amylolytic gene expression in the koji mold Aspergillus oryzae. Biosci Biotechnol Biochem 83(8):1385-1401

Govender N, Wong MY (2017) Detection of oil palm root penetration by Agrobacterium-mediated transformed Ganoderma boninense, expressing green fluorescent protein. Phytopathology 107(4):483-490

Gurung N, Ray S, Bose S, Rai V (2013) A broader view: microbial enzymes and their relevance in industries, medicine, and beyond. Biomed Res Int. https://doi.org/10.1155/2013/329121

Hajjaj H, Duboc P, Fay LB, Zbinden I, Macé K, Niederberger P (2005) Aspergillus oryzae produces compounds inhibiting cholesterol biosynthesis downstream of dihydrolanosterol. FEMS Microbiol Lett 242(1):155-159

He B, Hu Z, Ma L, Li H, Ai M, Han J, Zeng B (2018a) Transcriptome analysis of different growth stages of Aspergillus oryzae reveals dynamic changes of distinct classes of genes during growth. BMC Microbiol 18(1):1-12

He B, Tu Y, Hu Z, Ma L, Dai J, Cheng X, Li H, Liu L, Zeng B (2018b) Genome-wide identification and expression profile analysis of the HOG gene family in Aspergillus oryzae. World J Microbiol Biotechnol 34(2):1-35

He B, Tu Y, Jiang C, Zhang Z, Li Y, Zeng B (2019) Functional genomics of Aspergillus oryzae: strategies and progress. Microorganisms 7(4):103

Hoa BT, Hung PV (2013) Optimization of nutritional composition and fermentation conditions for cellulase and pectinase production by Aspergillus oryzae using response surface methodology. Int Food Res J 20(6):3269-3274

Hoang HD, Maruyama Jl, Kitamoto K (2015) Modulating endoplasmic reticulum-Golgi cargo receptors for improving secretion of carrier-fused heterologous proteins in the filamentous fungus Aspergillus oryzae. Appl Environ Microbiol 81(2):533-543

Huynh HH, Morita N, Sakamoto T, Katayama T, Miyakawa T, Tanokura M, Chiba Y, Shinkura R, Maruyama JI (2020) Functional production of human antibody by the filamentous fungus Aspergillus oryzae. Fungal Biology and Biotechnology 7(1):1-15

Iftikhar T, Niaz M, Jabeen R, Haq IU (2011) Purification and characterization of extracellular lipases. Pak J Bot 43(3):1541-1545

James JA, Lee BH (1997) Glucoamylases: microbial sources, industrial applications and molecular biology: A review. J Food Biochem 21:1-52

Ji L, Wang J, Luo Q, Ding Q, Tang W, Chen X, Liu L (2021) Enhancing L-malate production of Aspergillus oryzae by nitrogen regulation strategy. Appl Microbiol Biotechnol 105:3101-3113
Jiang D, Zhu W, Wang Y, Sun C, Zhang KQ, Yang J (2013) Molecular tools for functional genomics in filamentous fungi: recent advances and new strategies. Biotechnol Adv 31(8):1562-1574

Jin FJ, Maruyama JI, Juvvadi PR, Arioka M, Kitamoto K (2004a) Development of a novel quadruple auxotrophic host transformation system by argB gene disruption using adeA gene and exploiting adenine auxotrophy in Aspergillus oryzae. FEMS Microbiol Lett 239(1):79-85

Jin FJ, Maruyama Jl, Juvvadi PR, Arioka M, Kitamoto K (2004b) Adenine auxotrophic mutants of Aspergillus oryzae: development of a novel transformation system with triple auxotrophic hosts. Biosci Biotechnol Biochem 68(3):656-662

Jin FJ, Hu S, Wang BT, Jin L (2021) Advances in genetic engineering technology and its application in the industrial fungus Aspergillus oryzae. Front Microbiol 12:353-366

Jørgensen TR (2007) Identification and toxigenic potential of the industrially important fungi, Aspergillus oryzae and Aspergillus sojae. J Food Prot 70(12):2916-2934

Katayama T, Tanaka Y, Okabe T, Nakamura H, Fujii W, Kitamoto K, Maruyama JI (2016) Development of a genome editing technique using the CRISPR/ Cas9 system in the industrial filamentous fungus Aspergillus oryzae. Biotech Lett 38(4):637-642

Ketipally R, Raghu Ram M (2018) Optimization of pectinase production by Aspergillus oryzae RR 103. Curr Agri Res J 6(1):37-44

Kim SH, Yu DJ, Lee SJ, Park SY, Ryu KS, Lee DG (2003) Effects of feeding Aspergillus oryzae ferments on performance, intestinal microflora, blood serum components and environmental factors in broiler. Korean J Poult Sci 30:151-159

King AM, Reid-Yu SA, Wang W, King DT, De Pascale G, Strynadka NC, Walsh TR, Coombes BK, Wright GD (2014) Aspergillomarasmine A overcomes metallo- $\beta$-lactamase antibiotic resistance. Nature 510(7506):503-506

Kitamoto K (2015) Cell biology of the Koji mold Aspergillus oryzae. Biosci Biotechnol Biochem 79(6):863-869

Klich MA (2007) Aspergillus flavus: the major producer of aflatoxin. Mol Plant Pathol 8:713-722

Kobayashi T, Abe K, Asai K, Gomi K, Juvvadi PR, Kato M, Kitamoto K, Takeuchi M, Machida M (2007) Genomics of Aspergillus oryzae. Biosci Biotechnol Biochem 71(3):646-670

Kotnik T, Frey W, Sack M, Meglič SH, Peterka M, Miklavčič D (2015) Electroporation-based applications in biotechnology. Trends Biotechnol 33(8):480-488

Krijgsheld P, Bleichrodt RV, Van Veluw GJ, Wang F, Müller WH, Dijksterhuis J, Wösten HAB (2013) Development in Aspergillus. Stud Mycol 74:1-29

Kubodera T, Yamashita N, Nishimura A (2000) Pyrithiamine resistance gene (ptrA) of Aspergillus oryzae: cloning, characterization and application as a dominant selectable marker for transformation. Biosci Biotechnol Biochem 64:1416-1421

Kück U, Hoff B (2010) New tools for the genetic manipulation of filamentous fungi. Appl Microbiol Biotechnol 86(1):51-62

Kumar P, Mahato DK, Kamle M, Mohanta TK, Kang SG (2017) Aflatoxins: a global concern for food safety, human health and their management. Front Microbiol 7:2170

Kusumoto Kl, Nogata Y, Ohta H (2000) Directed deletions in the aflatoxin biosynthesis gene homolog cluster of Aspergillus oryzae. Curr Genet 37:104-111

Lakshmi M, Jyothi P (2014) Production and optimization of glucoamylase from Aspergillus oryzae NCIM 1212 using wheat bran, varying chemical parameters under solid state fermentation. Int J Curr Microbiol App Science 3(5):70-76

Lee K, Lee SK, Lee BD (2006) Aspergillus oryzae as probiotic in poultry-A review. Int J Poultry Sci 5:1-3

Lee JH, Jo EH, Hong EJ, Kim KM, Lee I (2014) Safety evaluation of filamentous fungi isolated from industrial doenjang koji. J Microbiol Biotechnol 24(10):1397-1404

Li S, Cong Y, Liu Y, Wang T, Shuai Q, Chen N, Gai J, Li Y (2017) Optimization of Agrobacterium-mediated transformation in soybean. Front Plant Sci 8:246

Liang Y, Pan L, Lin Y (2009) Analysis of extracelular proteins of Aspergillus oryzae grown on soy sauce koji. Biosci Biotechnol Biochem 73:192-195

Lichius A, Ruiz DM, Zeilinger S (2020) Genetic transformation of filamentous fungi: achievements and challenges. In: Nevalainen $\mathrm{H}$ (ed) Grand challenges in fungal biotechnology. Springer, Cham, pp 123-164 
Lobato CC, Ordoñez ME, Queiroz RL, Santos CB, Borges RS (2020) A comparative study between kojic acid and its methylated derivatives as antioxidant related to maltol and alomaltol. Chem Data Collect 28:100464

Machida M (2002) Progress of Aspergillus oryzae genomics. Adv Appl Microbiol 51:81-106

Machida M, Asai K, Sano M, Tanaka T, Kumagai T, Terai G, Kusumoto Kl, Arima T, Akita O, Kashiwagi Y, Abe K (2005) Genome sequencing and analysis of Aspergillus oryzae. Nature 438(7071):1157-1161

Machida M, Yamada O, Gomi K (2008) Genomics of Aspergillus oryzae: learning from the history of Koji mold and exploration of its future. DNA Res 15:173-183

Marui J, Ohashi-Kunihiro S, Ando T, Nishimura M, Koike H, Machida M (2010) Penicillin biosynthesis in Aspergillus oryzae and its overproduction by genetic engineering. J Biosci Bioeng 110:8-11

Maruyama JI, Kitamoto K (2008) Multiple gene disruptions by marker recycling with highly efficient gene-targeting background ( $\triangle$ ligD) in Aspergillus oryzae. Biotech Lett 30(10):1811

Mei YZ, Zhu YL, Huang PW, Yang Q, Dai CC (2019) Strategies for gene disruption and expression in filamentous fungi. Appl Microbiol Biotechnol 103(15):6041-6059

Meneghel L, Reis GP, Reginatto C, Malvessi E, da Silveira MM (2014) Assessment of pectinase production by Aspergillus oryzae in growth-limiting liquid medium under limited and non-limited oxygen supply. Process Biochem 49:1800-1807

Miura D, Sugiyama K, Ito A, Ohba-Tanaka A, Tanaka M, Shintani T, Gomi K (2018) The PDR-type ABC transporters AtrA and AtrG are involved in azole drug resistance in Aspergillus oryzae. Biosci Biotechnol Biochem 82:1840-1848

Mohamad R, Mohamed MS, Suhaili N, Salleh MM, Ariff AB (2010) Kojic acid: applications and development of fermentation process for production. Biotechnol Mol Bio Rev 5:24-37

Moubasher AH (1993) Soil fungi in Qatar and other Arab countries. The Scientific And Applied Research Centre University of Qatar, Doha, p 566

Murphy MM, Baker LA, Robbins RD, Richeson JT, Pipkin JL (2021) 53 Effect of Aspergillus Niger and Oryzae on the digestibility of Coastal Bermudagrass and Teff hay in horses. J Equine Vet Sci 100:103516

Murthy PS, Sano M, Hattori R, Kusumoto KI, Suzuki S (2018) Aspergillus Oryzae Strain with Improved Conidiation after Light Stimulation. JARQ 52(1):23-28

Nakajima KI, Asakura T, Maruyama Jl, Morita Y, Oike H, Shimizu-lbuka A, Misaka T, Sorimachi H, Arai S, Kitamoto K, Abe K (2006) Extracellular production of neoculin, a sweet-tasting heterodimeric protein with taste-modifying activity, by Aspergillus oryzae. Appl Environ Microbiol 72:3716-3723

Nakamura S (1960) Muta-aspergillic acid, a new growth inhibitant against hiochi-bacteria. Bull Agri Chem Soc Japan 24:629-630

Nakamura H, Kikuma T, Jin FJ, Maruyama JI, Kitamoto K (2016) AoRim15 is involved in conidial stress tolerance, conidiation and sclerotia formation in the filamentous fungus Aspergillus oryzae. J Biosci Bioeng 121:365-371

Newsome R, Tran N, Paoli GM, Jaykus LA, Tompkin B, Miliotis M, Ruthman T, Hartnett E, Busta FF, Petersen B, Shank F (2009) Development of a riskranking framework to evaluate potential high-threat microorganisms, toxins, and chemicals in food. J Food Sci 74:R39-R45

Nguyen KT, Ho QN, Pham TH, Phan TN, Tran VT (2016) The construction and use of versatile binary vectors carrying pyrG auxotrophic marker and fluorescent reporter genes for Agrobacterium-mediated transformation of Aspergillus oryzae. World J Microbiol Biotechnol 32(12):204

Nguyen KT, Ho QN, Do LT, Mai LT, Pham DN, Tran HT, Le DH, Nguyen HQ, Tran VT (2017) A new and efficient approach for construction of uridine/uracil auxotrophic mutants in the filamentous fungus Aspergillus oryzae using Agrobacterium tumefaciens-mediated transformation. World J Microbiol Biotechnol 33(6):107

Nishimura A, Okamoto S, Yoshizako F, Morishima I, Ueno T (1991) Stimulatory effect of acetate and propionate on aspergillic acid formation by Aspergillus oryzae A 21. J Ferment Bioeng 72:461-464

Nizamuddin S, Sridevi A, Narasimha G (2008) Production of $\beta$-galactosidase by Aspergillus oryzae in solid-state fermentation. Afr J Biotech 7(8):1096-1100

Nødvig CS, Nielsen JB, Kogle ME, Mortensen UH (2015) A CRISPR-Cas9 system for genetic engineering of filamentous fungi. PLOS ONE 10(7):e0133085
Ntana F, Mortensen UH, Sarazin C, Figge R (2020) Aspergillus: A powerful protein production platform. Catalysts 10(9):1064

Ogawa M, Tokuoka M, Jin FJ, Takahashi T, Koyama Y (2010) Genetic analysis of conidiation regulatory pathways in koji-mold Aspergillus oryzae. Fungal Genet Biol 47(1):10-18

Olempska-Beer Z, (2007) Asparaginase from Aspergillus oryzae encoded by the asparaginase gene from $A$. oryzae. Chem Tech Ass (CTA), pp 1-7.

Parbat R, Singhal B (2011) Production of glucoamylase by Aspergillus oryzae under solid state fermentation using agro industrial products. Int J Microbiol Res 2:204-207

Park HS, Lee MK, Han KH, Kim MJ, Yu JH (2019) Developmental decisions in Aspergillus nidulans. In: Hoffmeister D, Gressler M (eds) Biology of the fungal cell. Springer, Cham, pp 63-80

Patel GB, Mackenzie CR, Agnew BJ (1985) Properties and potential advantages of $\beta$-galactosidase from Bacteroides polypragmatus. Appl Microbiol Biotechnol 22:114-120

Pfefferle W, Anke H, Bross M, Steffan B, Vianden R, Steglich W (1990) Asperfuran, a novel antifungal metabolite from Aspergillus oryzae. J Antibiotics 43:648-654

Pinheiro VE, Desagiacomo CC, Michelin M, Maller A, Monteiro LM, Jorge JA, Polizeli MD (2017) Neosartoryaglabra polygalacturonase produced from fruit peels as inducers has the potential for application in passion fruit and apple juices. Braz J Food Technol 20:1-11

Priji P, Sajith S, Faisal PA, Benjamin S (2016) Microbial lipases_-Properties and applications. J Microbiol Biotechnol Food Sci 6:799-807

Raimbault M (1998) General and microbiological aspects of solid substrate fermentation. Electron J Biotechnol 1(3):174-188

Ram MR, Kumar S (2018) Production of alkaline protease from Aspergillus oryzae isolated from seashore of Bay of Bengal. J Appl Nat Sci 10(4):1210-1215

Ramachandran S, Patel AK, Nampoothiri KM, Chandran S, Szakacs G, Soccol CR, C.R., Pandey, A. (2004) Alpha Amylase from a Fungal Culture Grown on Oil Cakes and Its Properties. Braz Arch Biol Technol 47(2):309-317

Ramakrishna V, Rajasekhar S, Reddy LS (2010) Identification and purification of metalloprotease from dry grass pea (Lathyrussativus L) seeds. Appl Biochem Biotechnol 160(1):63-71

Ramakrishnan CV, Sathe V (1956) Effect of vitamin K3 on inducing its biosynthesis in moulds. Sci Cult (calcutta) 22:340

Ramirez-Prado JH, Moore GG, Horn BW, Carbone I (2008) Characterization and population analysis of the mating-type genes in Aspergillus flavus and Aspergillus parasiticus, Fungal Genet. Biol 45:1292-1299

Rand TG, Chang CT, McMullin DR, Miller JD (2017) Inflammation associated gene expression in RAW 264.7 macrophages induced by toxins from fungi common on damp building materials. Toxicol in Vitro 43:16-20

Raveendran S, Parameswaran B, Ummalyma S, Abraham S, Mathew A, Madhavan A, Rebello S, Pandey A (2018) Applications of microbial enzymes in food industry. Food Technol Biotechnol 56(1):16-30

Rebollar-Pérez G, Romero-Guido C, Baez A, Torres E (2019) Halogenases with potential applications for the synthesis of halogenated pharmaceuticals. In: Grunwald P (ed) Pharmaceutical biocatalysis. Jenny Stanford Publishing, Singapore, pp 579-602

Reichelt JR (1983). In: Godfrey RJ (ed) Industrial enzymology. Nature Press, New York, $\mathrm{p} 138$

Rodriguez VB, Alameda EJ, Gallegos J, Requena AR, Lopez A (2006) Enzymatic hydrolysis of soluble starch with an alpha amylase from Bacillus licheniformis. Biotechnol Progr 22(3):718-722

Saeedi M, Eslamifar M, Khezri K (2019) Kojic acid applications in cosmetic and pharmaceutical preparations. Biomed Pharmacother 110:582-593

Sakai H (1953) On vitamin B12 production by fermentation. Part. 2. Production test of B12 by various microorganisms. J Agr Chem Soc Japan 27:405-407

Sher H, Faheem M, Ghani A, Mehmood R, Rehman H, Bokhari SA (2017) Optimization of cellulase enzyme production from Aspergillus oryzae for industrial applications. World J Biol Biotechnol 2(2):155-158

Silva TAS, Knob A, Tremacoldi CR, Brochetto- Braga MR, Carmona EC (2011) Purification and some properties of an extracellular acid protease from Aspergillus clavatus. World J Microbiol Biotechnol 27(11):2491-2497

Son YE, Park HS (2020) Genetic manipulation and transformation methods for Aspergillus spp. Mycobiology. https://doi.org/10.1080/12298093.2020. 1838115 
Son SY, Lee S, Singh D, Lee NR, Lee DY, Lee CH (2018) Comprehensive secondary metabolite profiling toward delineating the solid and submergedstate fermentation of Aspergillus oryzae KCCM 12698. Front Microbiol 9:1076

Steensels J, Gallone B, Voordeckers K, Verstrepen KJ (2019) Domestication of industrial microbes. Curr Biol 29(10):R381-R393

Subramaniyam R, Vimala R (2012) Solid state and submerged fermentation for the production of bioactive substances: a comparative study. J Sci Nat 3(3):480-486

Suzuki S, Tada S, Fukuoka M, Taketani H, Tsukakoshi Y, Matsushita M, Oda K, Kusumoto Kl, Kashiwagi Y, Sugiyama M (2009) A novel transformation system using a bleomycin resistance marker with chemosensitizers for Aspergillus oryzae. Biochem Biophys Res Commun 383(1):42-47

Tada S, Matsushita-Morita M, Suzuki S, Kusumoto Kl, Kashiwagi Y (2009) Characterization of a neutral ceramidase orthologue from Aspergillus oryzae. FEMS Microbiol Lett 298(2):157-165

Takamine J (1894) United States Patents 525,820 and 525,823. Turner, W.B. 1975. Commercially important secondary metabolites. In: Smith JE, Berry DK. (eds) The Filamentous Fungi, Industrial Mycology, vol 1. Wiley, pp. 122-142.

Taylor MJ, Richardson T (1979) Applications of microbial enzymes in food systems and in biotechnology. Adv Appl Microbiol 25:7-35

Timofeev S, Tsarev A, Senderskiy I, Rogozhin E, Mitina G, Kozlov S, Dolgikh $V$ (2019) Efficient transformation of the entomopathogenic fungus Lecanicillium muscarium by electroporation of germinated conidia. Mycoscience 60(3):197-200

Tsuchiya K, Tada S, Gomi K, Kumagai C, Jigami Y, Tamura G (1992) High levelexpression of the synthetic human lysozyme gene in Aspergillus oryzae. Appl Microbiol Biotechnol 38(1):109-114

Ullah M, Xia L, Xie S, Sun S (2020) CRISPR/Cas9-based genome engineering: A new breakthrough in the genetic manipulation of filamentous fungi. Biotechnol Appl Biochem. https://doi.org/10.1002/bab.2077

Van den Berg MA, Maruthachalam K (eds) (2015) Genetic Transformation Systems in Fungi, vol 2. Springer International Publishing, Cham, pp 8-15

Wada R, Maruyama J-I, Yamaguchi H (2012) Presence and functionality of mating type genes in the supposedly asexual filamentous fungus Aspergillus oryzae. Appl Environ Microbiol 78:2819-2829

Wang D, He D, Li G, Gao S, Lv H, Shan Q, Wang L (2014) An efficient tool for random insertional mutagenesis: Agrobacterium tumefaciens-mediated transformation of the filamentous fungus Aspergillus terreus. J Microbiol Methods 98:114-118

Wang S, Chen H, Tang X, Zhang H, Chen W, Chen YQ (2017) Molecular tools for gene manipulation in filamentous fungi. Appl Microbiol Biotechnol 101(22):8063-8075

Watarai N, Yamamoto N, Sawada K, Yamada T (2019) Evolution of Aspergillus oryzae before and after domestication inferred by large-scale comparative genomic analysis. DNA Res 26(6):465-472

Xu D, Pan L, Zhao H, Zhao M, Sun J, Liu D (2011) Breeding and identification of novel koji molds with high activity of acid protease by genome recombination between Aspergillus oryzae and Aspergillus niger. J Ind Microbiol Biotechnol 38(9):1255-1265

Yamada O, Ikeda R, Ohkita Y, Hayashi R, Sakamoto K, Akita O (2007) Gene silencing by RNA interference in the koji mold Aspergillus oryzae. Biosci Biotechnol Biochem 71(1):138-144
Yamada R, Yoshie T, Wakai S, Asai-Nakashima N, Okazaki F, Ogino C, Hisada H, Tsutsumi H, Hata Y, Kondo A (2014) Aspergillus oryzae-based cell factory for direct kojic acid production from cellulose. Microb Cell Fact 13(1):71

Yasui M, Oda K, Masuo S, Hosoda S, Katayama T, Maruyama Jl, Takaya N, Takeshita N (2020) Invasive growth of Aspergillus oryzae in rice koji and increase of nuclear number. Fungal Biol Biotechnol 7:1-15

Yokota Jl, Shiro D, Tanaka M, Onozaki Y, Mizutani O, Kakizono D, Ichinose S, Shintani T, Gomi K, Shintani T (2017) Cellular responses to the expression of unstable secretory proteins in the filamentous fungus Aspergillus oryzae. Appl Microbiol Biotechnol 101(6):2437-2446

Yoon J, Aishan T, Maruyama JI, Kitamoto K (2010) Enhanced production and secretion of heterologous proteins by the filamentous fungus Aspergillus oryzae via disruption of vacuolar protein sorting receptor gene Aovps 10. Appl Environ Microbiol 76(17):5718-5727

Yoon J, Maruyama Jl, Kitamoto K (2011) Disruption of ten protease genes in the filamentous fungus Aspergillus oryzae highly improves production of heterologous proteins. Appl Microbiol Biotechnol 89(3):747-759

Yoshino-Yasuda S, Mori A, Ishihara N, Hasegawa O, Kato M, Kitamoto N (2011) Development of a highly efficient gene replacement system for an industrial strain of Aspergillus oryzae used in the production of miso, a Japanese fermented soybean paste. Food Sci Technol Res 17(2):161-166

Yu JH (2010) Regulation of development in Aspergillus nidulans and Aspergillus fumigatus. Mycobiology 38:229-237

Yu XC, Ma SL, Xu Y, Fu CH, Jiang CY, Zhou CY (2017) Construction and application of a novel genetically engineered Aspergillus oryzae for expressing proteases. Elec J Biotechnol 29:32-38

Zambare V (2010) Solid state fermentation of Aspergillus oryzae for glucoamylase production on agro residues. Int J Life Sci 4:16-25

Zhang J, Wang S, Wei Q, Guo Q, Bai Y, Yang S, Song F, Zhang L, Lei X (2017a) Synthesis and biological evaluation of Aspergillomarasmine A derivatives as novel NDM-1 inhibitor to overcome antibiotics resistance. Bioorganic Med Chem 25:5133-5141

Zhang S, Ban A, Ebara N, Mizutani O, Tanaka M, Shintani T, Gomi K (2017b) Self-excising $\mathrm{Cre} /$ mutant lox marker recycling system for multiple gene integrations and consecutive gene deletions in Aspergillus oryzae. J Biosci Bioeng 123(4):403-411

Zhong Y, Lu X, Xing L, Ho SWA, Kwan HS (2018) Genomic and transcriptomic comparison of Aspergillus oryzae strains: a case study in soy sauce koji fermentation. J Ind Microbiol Biotechnol 45(9):839-853

Zhou M, Zhou K, He P, Wang KM, Zhu RZ, Wang YD, Dong W, Li GP, Yang HY, Ye YQ, Du G (2016) Antiviral and cytotoxic isocoumarin derivatives from an endophytic fungus Aspergillus oryzae. Planta Med 82(5):414-417

Zhu L, Maruyama Jl, Kitamoto K (2013) Further enhanced production of heterologous proteins by double-gene disruption ( $\triangle$ AosedD $\triangle$ Aovps 10 ) in a hyper-producing mutant of Aspergillus oryzae. Appl Microbiol Biotechnol 97(14):6347-6357

\section{Publisher's Note}

Springer Nature remains neutral with regard to jurisdictional claims in published maps and institutional affiliations.

\section{Submit your manuscript to a SpringerOpen ${ }^{\odot}$ journal and benefit from:}

- Convenient online submission

- Rigorous peer review

- Open access: articles freely available online

- High visibility within the field

- Retaining the copyright to your article

Submit your next manuscript at $\boldsymbol{\nabla}$ springeropen.com 